\title{
PARTISIPASI MASYARAKAT TERHADAP PEMBANGUNAN INFRASTRUKTUR JALAN PERTANIAN MELALUI DANA DESA DI DESA BUHIAS KECAMATAN WORI KABUPATEN MINAHASA UTARA
}

\author{
Michael Papudi \\ Melsje Yellie Memah \\ Martha Mareyke Sendow
}

Naskah diterima melalui Website Jurnal Ilmiah agrisosioekonomi@unsrat.ac.id

: Jumat, 11 Oktober 2019

Disetujui diterbitkan

: Rabu, 23 Oktober 2019

\begin{abstract}
This study aims to determine community participation in the planning and implementation stages in the construction of agricultural road infrastructure funded by the Village Fund in Buhias Village, Mantehage Island, Wori Sub-district, North Minahasa Regency. The 3-month study was conducted from August to October 2018. Primary data were obtained through interviews, based on a list of questions, to 20 respondents who were chosen based on pusposive sampling method. Secondary data were obtained from the Buhias Village Office, from local bookstores, as well as from the internet through Google searching to obtain journal articles and theses relating to research topics, especially concerning community participation in road infrastructure development. Data analysis using descriptive analysis presented in tabular form. The results showed that community participation in the construction of agricultural road infrastructure in the village of Buhias was in the medium category at the planning stage and in the high category at the stage of implementing agricultural road construction. ${ }^{*{ }^{2} \mathrm{prm}^{*}}$
\end{abstract}

Keywords: participation, agricultural road infrastructure, village funds.

\begin{abstract}
ABSTRAK
Penelitian ini bertujuan untuk mengetahui partisipasi masyarakat pada tahap perencanaan dan dan pelasaksanaan dalam pembangunan infrastruktur jalan pertanian yang didanai dengan Dana Desa di Desa Buhias, Pulau Mantehage, Kecamatan Wori, Kabupaten Minahasa Utara. Pelaksanaan penelitian dilakukan mulai dari bulan Agustus sampai bulan Oktober 2018. Data primer diperoleh melalui wawancara berdasarkan pedoman daftar pertanyaan pada 20 responden yang dipilih secara sengaja (pusposive sampling). Data sekunder di peroleh dari Kantor Desa Buhias, dari buku yang berasal dari toko buku lokal, serta internet melalui google searching untuk mendapatkan artikel jurnal dan skripsi yang berkaitan dengan topik penelitian terutama menyangkut partisipasi masyarakat dalam pembangunan infrastruktur jalan. Analisis data menggunakan analisis deskriptif yang disajikan dalam bentuk tabel. Hasil penelitian menunjukkan bahwa partisipasi masyarakat dalam pembangunan infrastruktur jalan pertanian di Desa Buhias berada pada kategori sedang pada tahap perencanaan dan berada pada kategori tinggi pada tahap pelaksanaan pembangunan jalan pertanian. ${ }^{* e p r m *}$
\end{abstract}

Kata kunci : partisipasi, infrastruktur jalan pertanian, dana desa. 


\section{PENDAHULUAN}

\section{Latar Belakang}

Reformasi dan arus desentralisasi Undang-Undang Nomor 22 tahun 1999 tentang pemerintahan daerah diubah dengan UndangUndang Nomor 32 tahun 2004, paradigma pembangunan nasional telah mengalami suatu perubahan yang signifikan, dari pembangunan yang bertumpu pada negara menjadi paradigma pembangunan yang bertumpu pada masyarakat perdesaan.

Program pembangunan infrastruktur jalan pertanian melalui dana Desa Tahun 2018, program dana Desa diadakan seluruh perdesaan, dan salah satunya dilaksanakan di Desa Buhias menjadi jenis kegiatan adalah pembangunan jalan pertanian, dan berupa jalan Talut. Dengan angaran yang digunakan dalam pembangunan ini adalah Rp.700,000,000; (Tujuh ratus juta rupiah), dimana Rp.700,000,000; tersebut dana bantuan dari pemerintah melalui dana Desa oleh karena itu pemerintah Desa Buhias memperlibatkan semua masyarakat untuk membangun jalan pertanian untuk mengakseskan hasil perekonomian, sehingga jalan tersebut sangat membantu masyarakat untuk melancarkan hasil perekonomian mereka.

Paradigma pembangunan yang sangat dikembangkan sekarang ini adalah paradigma pemberdayaan yang berintikan partisipasi masyarakat, masyarakat ditempatkan sebagai pelaku utama pembangunan dan pemerintah tidak lagi sebagai provider, tetapi lebih bertindak sebagai intermediasi dan katalisator segenap perencanaan pembangunan.Artinya pemerintah Desa seharusnya memberikan kepercayaan dan kesempatan yang lebih banyak kepada anggota masyarakat, didalam menumbuh kembangkan segala potensi yang dimilikinya bersama dengan lingkungannya. Bagaimana mengkondisikan agar pembangunan menjadi bagian integral dari rakyat,sehingga mereka berperan sebagai subyek pembangunan yang dominan menentukan keberhasilan pembangunan. Pembangunan partisipatif harus dimulai dengan masyarakat sebagai manusia yang memiliki aspirasi dan paling mengetahui tentang kebutuhannya.

\section{Konsep Partisipasi Masyarakat}

Menurut Adisasmita (2006), mengatakan bahwa partisipasi masyarakat adalah keterlibatan anggota masyarakat dalam pembangunan, meliputi kegiatan dalam perencanaan dan pelaksanaan (implementasi) program/proyek pembangunan yang dikerjakan di dalam masyarakat lokal. Dalam sebuah pembangunan, partisipasi masyarakat merupakan salah satu aspek yang perlu diperhatikan.Pembangunan masyarakat diarahkan pada perbaikan kondisi hidup masyarakat.Pembangunan masyarakat sebagai upaya untuk mengubah keadaan dari yang kurang dikehendaki menuju keadaan yang lebih baik.Oleh karena itulah partisipasi masyarakat merupakan salah satu aspek yang dapat menentukan keberhasilan suatu pembangunan tersebut.

\section{Pengertian Partisipasi Masyarakat}

Untuk mewujudkan keberhasilan pembangunan, inisiatif, dan kreatifitas dari keanggotaan masyarakat yang lahir dari kesadaran dan tanggung jawab sebagai manusia yang hidup bermasyarakat dan diharapkan tumbuh berkembang sebagai suatu partisipasi, pengertian partisipasi masyarakat adalah kesediaan masyarakat untuk ikut terlibat secara fisik maupun emosional serta bertanggung jawab terhadap suatu kegiatan.

Menurut Isbandi (2007), Partisipasi masyarakat adalah keikutsertaan masyarakat dalam proses pengidentifikasian masalah dan potensi yang ada dimasyarakat, pemilihan dan pengambilan keputusan tentang alternatif solusi untuk menangani masalah, pelaksanaan upaya mengatasi masalah, dan keterlibatan masyarakat dalam proses mengevaluasi perubahan yang terjadi. MenurutKodoatie, Robert J. (2005), terdapat empat jenjang yang terdapat dalam partisipasi masyarakat

\section{Pentingnya Partisipasi Masyarakat}

Infrastruktur merujuk pada sistem fisik yang menjediakan transportasi, pengairan, drainase, bangunan-bangunan gedung, dan fasilitas publik yang lain yang dibutuhkan untuk memenuhi kebutuhan dasar manusia dalam lingkup sosial dan ekonomi.Sistem infrastruktur merupakan pendukung utama fungsi-fungsi sosial dan sistem ekonomi dalam kehidupan sehari-hari masyarakat. Pada dasarnya penyediaan infrastruktur dilaksanakan oleh masing-masing individu, sama halnya dengan pemenuhan kebutuhan - kebutuhan dasar lainnya seperti sadang dan pangan. 


\section{Jenis-jenis Partisipasi Masyarakat}

Menurut Santoso (1988), Jenis partisipasi meliputi (1) Pemikiran (2) Tenaga (3) Pemikiran dan Tenaga (4) Keahlian (5) Barang (6) Uang. Menjabarkan jenis partisipasi sebagai berikut:

1. Partisipasi pemikiran adalah partisipasi berupa sumbangan ide, pendapat atau buah pikiran konstruktif, baik untuk menyusun program, maupun untuk memperlancar pelaksanaan program dan juga untuk mewujudkannya dengan memberikan pengalaman dan pengetahuan guna mengembangkan kegiatan yang diikutinya.

2. Partispasi tenaga adalah partisipasi yang diberikan dalam bentuk tenaga untuk pelaksanaan usaha-usaha yang dapat menunjang keberhasilan suatu program.

3. Partisipasi Pikiran dan Tenaga adalah dimana tingkat partisipasi tersebut dilakukan bersama-sama dalam suatu kelompok dalam mencapai tujuan yang sama.

\section{Bentuk Partisipasi Masyarakat}

Bentuk partisipasi masyarakat merujuk pada wujud kontribusi masyarakat dalam keikutsertaannya. Wujud kontribusi dari partisipasi masyarakat sudah barang tentu tergantung pada tahapan proses pelaksanaan program, karena wujud kontribusi tersebut akan berbeda pada setiap tahapan. Misalkan dalam tahapan partisipasi pada pengambilan keputusan, maka wujud kontribusi dari partisipasi masyarakat berupa sumbangan pemikiran dimana yang menjadi tolak ukurnya adalah banyaknya usul dan saran atau bahkan penolakan.

\section{Pengertian Pembangunan Infrastruktur Jalan \\ Menurut Adi Isbandi, Rukminto.} (2007), Infrastruktur jalan adalah segala bentuk prasarana yang merujuk pada bentuk fasilitasfasilitas fisik yang mendukung kegiatan manusia infrastruktur merujuk pada sistem fisik yang menyediakan transfortasi, pengairan, drainase, bangunan-bangunan gedung dan fasilitas publik yang lain yang dibutuhkan untuk memenuhi kebutuhan dasar manusia dalam lingkup sosial dan ekonomi, menyatakan bahwa Infrastruktur merupakan pendukung utama fungsifungsi sistem dan sistem ekonomi dalam kehidupan sehari-hari bagi masyarakat.

\section{Faktor-faktor yang mempengaruhi partisipasi masyarakat}

Ada beberapa faktor yang menghambat partisipasi masyarakat dalam suatu program, timbulnya partisipasi merupakan ekspresi perilaku manusia untuk melakukan suatu tindakan. Watson (dalam Soetomo, 2008), mengatakan bahwa ada beberapa kendala (hambatan) yang dapat menghalangi terjadinya suatu perubahan antara lain kendala yang berasal dari kepribadian individu salah satunya adalah ketergantungan.

\section{Rumusan Masalah}

Berdasarkan latar belakang diatas, maka yang menjadi rumusan masalah dalam penelitian ini adalah bagaiman tingkat partisipasi masyarakat terhadap pembangunan infrastruktur jalan pertanian di Desa Buhias Kecamatan Wori Kabupaten Minahasa Utara.

\section{Tujuan Penelitian}

Tujuan dari penelitian ini adalah untuk mengetahui partisipasi masyarakat terhadap pembangunan infrastruktur jalan pertanian melalui Dana Desa (Dandes) di Desa Buhias Kecamatan Wori Kabupaten Minahasa Utara.

\section{Manfaat Penelitian}

Penelitian ini diharapkan dapat bermanfaat bagi:

1. Masyarakat

Menambahkan pengetahuan kepada masyarakat agar masyarakat dapat memahami tentang pembangunan infrastruktur jalan pertanian 2. Penulis

Selain untuk penyelesaian studi akhir, juga dapat menambahkan pemahaman dan pengetahuan kepada penulis tentang bagaimana tangkapan masyarakat terhadap pembangunan infrastruktur jalan pertanian.

\section{METODE PENELITIAN}

\section{Waktu dan Tempat Penelitian}

Penelitian ini berlangsung selama 3 bulan sejak bulan Juni sampai bulan Agustus 2018. Tempat penelitian di Desa Buhias Kecamatan Wori Kabupaten Minahasa Utara. 


\section{Metode Pengumpulan Data}

Data yang akan digunakan dalam penelitian ini adalah data primer dan data sekunder.Data primer merupakan data yang diperoleh dari lapangan tempat penelitian melalui daftar pertanyaan atau kuesioner. Data sekunder yaitu data yang diperoleh dari pemerintah Desa Buhias, serta karya tulis ilmiah yang berhubungan dengan penelitian.

\section{Metode Pengambilan Sampel}

Pengambilan sampel mengunakan metode proposif sampling, jumlah responden sebanyak 20 , orang yang merupakan masyarakat dari 4 jaga masing-masing jaga 5, (Lima) orang yang terlibat dalam pembangunan infrastruktur jalan pertanian.

\section{Konsep Pengukuran Variabel}

Variabel yang diukur dalam penelitian ini adalah:

1. Karakteristik dari masyarakat

2. Umur Responden

3. Pekerjaan Responden

4. Tingkat Pendidikan Responden

5. Partisipasi responden dalam Program Pembangunan Infrastruktur jalan Pertanian yang dilaksanakan dari:

\section{Tahap Perencanaan}

1. Di tunjukkan bahwa dari tahap perencanaan yang Aktif mendapatkan skor (3) Responden memberikan partisipasi dalam bentuk:

- Ide atau saran dalam 4-6 kali pertemuan

2. Yang kurang Aktif medapatkan skor (2) Responden memberikan partisipasi dalam bentuk:

- Kehadiran dimana responden hadir lebih dari 1-3 kali pertemuan.

3. Yang tidak Aktif (1) Responden tidak memberikan partisipasi sama sekali.

\section{Tahap Pelaksanaan}

1. Di tunjukkan bahwa dari tahap pelaksanaan yang Aktif mendapatkan skor (3) Responden memberikan partisipasi dalam bentuk :

- Sumbang tenaga kerja dan peralatan, dalam setiap pelaksanaan pembangunan.

2. Yang kurang Aktif mendapatkan skor (2) Responden memberikan partisipasi dalam bentuk:

- Sumbangan kue atau the

3. Yang tidak Aktif (1) Responden tidak memberikan partisipasi sama sekali.

\section{Analisis Data}

Teknik analisis yang digunakan dalam penelitian ini adalah teknik analisis deskriptif kualitatif di sajikan dengan unsur tabel.

\section{HASIL DAN PEMBAHASAN}

\section{Deskripsi Daerah Penelitian Letak Geografis, dan Luas Wilayah, Batas Administrasi Kalimatologi}

Desa Buhias adalah salah satu Desa yang terletak di Kecamatan Wori Kabupaten Minahasa Utara Provinsi Sulawesi Utara dengan luas wilayah di Desa Buhias adalah $41.32 \mathrm{Km}$, dengan batas wilayah :
1. Sebelah Timur : Desa Tiwoho
2. Sebelah Barat : Desa Bango
3. Sebelah Selatan : Desa Tinongko

4. Sebelah Utara : Desa Tangkasi

Curah hujan $300 \mathrm{Mm}$, Jumlah Bulan Hujan 1-6 bulan, Kelembapan 137 Mm, Suhu rata-rata harian $41^{\circ} \mathrm{C}$

\section{Jumlah Penduduk di Desa Buhias}

Berdasarkan data Pemetaan jumlah penduduk Desa Buhias sebanyak 639 jiwa dengan jumlah kepala keluarga (KK) $318 \mathrm{KK}$. Yang menempati 4 jaga. Dilihat pada Tabel 1.

\begin{tabular}{|c|c|c|c|c|c|c|c|}
\hline $\begin{array}{c}\text { No } \\
\text { · }\end{array}$ & Jaga & $\mathbf{L}$ & $\mathbf{P}$ & $\begin{array}{c}\text { Jumla } \\
\mathbf{h}\end{array}$ & $\begin{array}{c}\text { Persentas } \\
\text { e } \\
(\%)\end{array}$ & $\begin{array}{l}\text { Jumla } \\
\text { h } \\
\text { (KK) }\end{array}$ & $\begin{array}{l}\text { Persentas } \\
\text { e }(\%)\end{array}$ \\
\hline 1. & 1 & 86 & 75 & 161 & 25.2 & 58 & 18.1 \\
\hline 2. & 2 & 79 & 60 & 139 & 21.4 & 89 & 27.8 \\
\hline 3. & 3 & 80 & 82 & 162 & 25.6 & 75 & 23.6 \\
\hline 4. & 4 & 89 & 92 & 181 & 28.6 & 96 & 30.5 \\
\hline & Tota & 33 & 30 & 643 & 100.8 & 318 & 100 \\
\hline & 1 & 4 & 9 & & & & \\
\hline
\end{tabular}

Pada Tabel 1. Menunjukkan bahwa jaga 1. Laki-laki 86 orang, Perempuan 75 orang, dan jaga 2. Laki-laki 79 orang, Perempuan 60 orang. Jaga 3. Laki-laki 80 orang, Perempuan 82 orang. Jaga 4. Laki-laki 89 orang, Perempuan 92 orang. 


\section{Umur Responden \\ Karakteristik Responden}

Berdasarkan dengan umur responden yang mempengaruhi tingkat partisipasi masyarakat. dapat perbedaan kedudukan dan derajat atas dasar dengan bervariasi, sehingga memunculkan usia tua dan muda, maka Produktivitas seseorang dapat dipengaruhi oleh umur, yaitu umur yang lebih muda tingkat produktivitas tinggi umur, $\leq 40$ tahun tingkat produktivitas lebih rendah. Dan hasil penelitian di Desa Buhias, umur responden dapat dilihat pada Tabel 2.ditunjukkan bahwa persentase terkecil adalah umur $\leq 40$ tahun yaitu sebanyak 7 orang atau $35 \%$ persen sedangkan presentase terbesar adalah berumur 41-50 yaitu 9 orang atau $45 \%$ persen, dan persentase terendah adalah umur $>50$ tahun yaitu sebanyak 4 orang atau $20 \%$ persen.

\section{Tabel 2. Jumlah Responden Menurut Umur}

\begin{tabular}{lccc}
\hline No. & Umur & $\begin{array}{c}\text { Jumlah } \\
\text { (Responden) }\end{array}$ & $\begin{array}{c}\text { Persentase } \\
(\boldsymbol{\%})\end{array}$ \\
\hline 1. & $\leq 40$ & 10 & 50 \\
2. & $41-50$ & 6 & 30 \\
3. & $>50$ & 4 & 20 \\
\hline & Total & 20 & 100 \\
\hline
\end{tabular}

Sumber Data: Diolah dari Data Primer, 2018.

Tabel 2 menunjukkan bahwa persentase terbesar adalah umur 40 tahun yaitu sebanyak 10 orang atau persen sedangkan presentase yang sedang adalah berumur 41-50 tahun yaitu sebanyak 6 orang atau persen, sedangkan presentase rendah adalah umur $>50$ tahun yaitu sebesar 4 orang atau persen.

\section{Pekerjaan Responden}

Pekerjaan merupakan partisipasi masyarakat dimana memiliki pekerjaan yang lebih tinggi dan juga jabatan yang berbeda setiap responden tingkat partisipasinya memiliki tingkat yang berbeda yaitu Petani dan PNS.
Tabel 3. Jumlah Responden Menurut Pekerjaan

\begin{tabular}{llcc}
\hline No. & Pekerjaan & $\begin{array}{l}\text { Jumlah } \\
\text { (Responden) }\end{array}$ & $\begin{array}{l}\text { Persentase } \\
(\boldsymbol{\%})\end{array}$ \\
\hline 1. & Petani & 19 & 95 \\
2. & PNS & 1 & 5 \\
\hline & Total & 20 & 100 \\
\hline
\end{tabular}

Sumber Data: Diolah dari Data Primer, 2018.

Tabel 3 menunjukkan bahwa menurut pekerjaan, responden merupakan petani dan PNS, yaitu dimana ada 19 orang atau 95\% dan dimana ada 1orang atau 5\% yang memiliki pekerjaan yang berbeda yaitu petani dan PNS.

\section{Tingkat Pendidikan}

Salah satu faktor yang mempengaruhi tingkat pengetahuan adalah tingkat pendidikan.Pendidikan semakin tinggi latar belakang pendidikan seseorang, tentunya mempunyai pengetahuan yang luas tentang pembangunan dan bentuk serta tata cara partisipasi yang dapat diberikan. Faktor pendidikan dianggap penting karena dengan pendidikan yang diperoleh, seseorang lebih mudah berkomunikasi dengan orang luar, dan cepat tanggap terhadap inovasi.Pendidikan juga merupakan kebutuhan pokok bagi setiap masyarakat dalam meningkatkan sumber daya manusia.Berdasarkan hasil penelitian, tingkat pendidikan responden bervariasi dan dapat dilihat pada Tabel 4.

\section{Tabel 4 Tingkat Pendidikan}

\begin{tabular}{llcc}
\hline No. & $\begin{array}{l}\text { Tingkat } \\
\text { Pendidikan }\end{array}$ & $\begin{array}{l}\text { Jumlah } \\
\text { (Responden) }\end{array}$ & $\begin{array}{l}\text { Persentase } \\
(\%)\end{array}$ \\
\hline 1. & SD & 10 & 50 \\
2. & SMP & 5 & 25 \\
3. & SMA & 4 & 20 \\
4. & PT & 1 & 5 \\
\hline \multicolumn{4}{r}{ Total } \\
\hline \multicolumn{2}{l}{ Sumber Data: Diolah dari Data Primer, 2018. }
\end{tabular}

Sumber Data: Diolah dari Data Primer, 2018.

Dari Tabel 4 menunjukkan bahwa tingkat pendidikan responden masih tergolong rendah dimana sebagian besar pada tingkat pendidikan SD 10 orang atau 50\%, dan SMP berjumlah 5 orang, atau $25 \%$, SMA berjumlah 4 orang atau $20 \%$, dan PT hannya 1 orang atau $5 \%$. 


\section{Partisipasi Responden dalam Program Pem-bangunan Infrastruktur Jalan Pertanian}

\section{Tahap Perencanaan}

Dalam tahap perencanaan pembangunan dibutuhkan keikutsertaan oleh masyarakat melalui tahapan-tahapan sebagaimana yang termuat dalam program yaitu dimulai dari pengalian gagasan pada tingkat jaga dan berlanjut pada musywarah Desa (Musdes) kegiatan musyawarah pembangunan ini dilaksanakan untuk menyerap aspirasi masyarakat Desa tentang kegiatan yang akan dilakukan pada program tersebut, kemudian diikut sertakan dalam musyawarah rencana pembangunan (Musrembang) tingkat kecamatan. Bentuk partisipasi masyarakat yang diberikan dalam tahap perencanaan adalah kehadiran dalam setiap rapat serta keaktifan dalam memberikan saran atau usulan. Untuk melihat bentuk partisipasi yang diberikan oleh masyarakat setempat, dapat dilihat pada Tabel 5.

Tabel 5. Bentuk Partisipasi Dari Masyarakat Dalam Pertemuan Ke 1

\begin{tabular}{llcc}
\hline No. & \multicolumn{1}{c}{$\begin{array}{c}\text { Bentuk } \\
\text { Partisipasi }\end{array}$} & $\begin{array}{c}\text { Jumlah } \\
\text { (Responden) }\end{array}$ & $\begin{array}{c}\text { Persentase } \\
(\mathbf{\%})\end{array}$ \\
\hline 1. & Aktif & 13 & 65 \\
2. & Kurang Aktif & 5 & 25 \\
3. & Tidak Aktif & 2 & 10 \\
\hline & Total & 20 & 100 \\
\hline
\end{tabular}

Sumber Data: Diolah dari Data Primer, 2018.

Tabel 5 menunjukkan bahwa 13 orang atau $65 \%$ yang memberikan partisipasi melalui kehadiran dan memberi saran atau usulan dalam setiap pertemuan, sedangakn 5 orang atau $25 \%$ memberikan partisipasi melalui kehadiran dan 2 orang atau $10 \%$ hanya menghadiri dalam pertemuan.

Tabel 6. Jumlah Responden Menurut Partisipasi Masyarakat Pada Tahap Perencanaan Dalam Pertemuan Ke 2

\begin{tabular}{llcc}
\hline No & $\begin{array}{c}\text { Partisipasi } \\
\text { Masyarakat }\end{array}$ & $\begin{array}{c}\text { Jumlah } \\
\text { (Responden) }\end{array}$ & Persentase (\%) \\
\hline 1. & Aktif & 15 & 75 \\
2. & Kurang Aktif & 4 & 20 \\
3. & Tidak Aktif & 1 & 5 \\
\hline & Total & 20 & 100 \\
\hline
\end{tabular}

Sumber Data: Diolah dari Data Primer, 2018.
Dari hasil kuesioner yang diberikan kepada setiap responden berkaitan dengan berpartisipasi pada tahap perencanaan dalam pembangunan infrastruktur jalan pertanian dengan jumlah yang aktif terbanyak 15 , orang atau $75 \%$ sedangkan responden yang kurang aktif 4 , orang atau $20 \%$, dan responden yang tidak hadir 1 , orang atau $5 \%$, seperti terlihat pada Tabel 6, pada kegiatan perencanaan dalam pertemuan yang ke 6 merupakan dalam bentuk partisipasi dari masyarakat melalui kehadiran dalam pertemuan dan memberikan ide atau pemikiran mengenai pembangunan infrastruktur jalan pertanian yang direcanakan oleh pemerintah Desa setempat.

\section{Tahap Pelaksanaan}

Tahap pelaksanaan merupakan tahap dimana fisik pembangunan infratruktur jalan pertanian ini dilakukan dari suatu program, dimana dibutuhkan kerja sama masyarakat dalam bentuk partisipasi, dalam pelaksanaan pembuatan jalan ini dengan partisipasi masyarakat diwujudkan dalam bentuk tenaga serta peralatan atau benda sekop, linggis, peda dan lain-lain.

Tabel 7. Bentuk Partisipasi Dari Masyarakat Pada Tahap Pelaksanaan

\begin{tabular}{llcc}
\hline No & $\begin{array}{l}\text { Bentuk } \\
\text { Partisipasi }\end{array}$ & $\begin{array}{l}\text { Jumlah } \\
\text { (Responden) }\end{array}$ & $\begin{array}{l}\text { Persentase } \\
(\%)\end{array}$ \\
\hline 1. & Tenaga dan & 5 & 25 \\
& Barang & 11 & 55 \\
2. & Tenaga & 4 & 20 \\
3. & Tidak & & \\
\hline & berpartisipasi & 20 & 100 \\
\hline
\end{tabular}

Sumber Data: Diolah dari Data Primer, 2018.

Dari hasil penelitian ini partisipasi masyarakat tenaga dan barang ada 5 orang atau $25 \%$, partisipasi masyarakat dalam bentuk tenaga ada 11 orang atau $55 \%$, partisipasi masyarakat tidak berpartisipasi ada 4 orang atau $20 \%$. Untuk mengetahui berapa besar partisipasi responden dalam program ini, dapat dilihat pada Tabel 7.

\section{Umur}

Berikut ini akan disajikan dalam bentuk Tabel Umur responden dengan partisipasi masyarakat dalam tahap pelaksanaa. 
Tabel 8. Jumlah Responden Dalam Paritisipasi Masyarakat menurut Umur Pada Progam Pembangunan Infrastruktur Jalan Pertanian Pada Tahap Pelaksanaan

\begin{tabular}{llccccc}
\hline No & Umur & Aktif & $\begin{array}{l}\text { Kurang } \\
\text { Aktif }\end{array}$ & $\begin{array}{l}\text { Tidak } \\
\text { Aktif }\end{array}$ & Jumlah & $\begin{array}{l}\text { Persentase } \\
(\%)\end{array}$ \\
\hline 1. & $\leq 40$ & 5 & 2 & 1 & 8 & 40 \\
2. & $41-50$ & 3 & 1 & 2 & 6 & 30 \\
3. & $>50$ & 3 & 2 & 1 & 6 & 30 \\
\hline & Total & 11 & 5 & 4 & 20 & 100 \\
\hline
\end{tabular}

Sumber Data: Diolah dari Data Primer, 2018.

Tabel 8. Memperlihatkan bahwa dimana umur $\leq 40$ tahun yang aktif 5 orang, kurang aktif 2 orang tidak aktif 1 orang, dari 8 orang atau $40 \%$. Pada umur 41-50 tahun aktif 3 orng kurang aktif 1 orang tidak aktif 2 orang dari 6 orang atau 30\%. Pada umur $>50$ tahun aktif 3 orang kurang aktif 2 orang tidak aktif 1 orang, dari 6 orang atau 30\%.

Tabel 9. Jumlah Responden Dalam Partisipasi Masyarakat menurut Perkerjaan dalam Pelaksanaan Program Pembangunan Infrastruktur Jalan Pertanian Pada Tahap Pelaksanaan

\begin{tabular}{|c|c|c|c|c|c|c|}
\hline No & $\begin{array}{c}\text { Pekerjaa } \\
\text { n }\end{array}$ & Aktif & $\begin{array}{l}\text { Kuran } \\
\text { g Aktif }\end{array}$ & $\begin{array}{c}\text { Tida } \\
\mathbf{k} \\
\text { Aktif }\end{array}$ & $\begin{array}{c}\text { Jumla } \\
\text { h }\end{array}$ & $\begin{array}{c}\text { Persentas } \\
\text { e (\%) }\end{array}$ \\
\hline 1. & Petani & 15 & 3 & 1 & 19 & 95 \\
\hline 2. & PNS & - & - & 1 & 1 & 5 \\
\hline & Total & 15 & 3 & 2 & 20 & 100 \\
\hline
\end{tabular}

Dari Tabel 9 menunjukkan bahwa dari 19 responden yang bekerja sebagai petani, yang aktif 15 orang yang kurang aktif 3 orang, yang tidak aktif 1 orang dari 19 orang atau $95 \%$. Sedangkan PNS hanya 1 responden juga tidak mengambil bagian dalam pelaksanaan.

\section{Pendidikan}

Tingkat pendidikan menunjukkan bahwa partisipasi masyarakat terhadap program pembangunan infrastruktur jalan pertanian menurut kategori pendidikan dalam tahap pelaksanaan.

Tabel 10. Jumlah Responden tingkat Partisipasi Masyarakat
Menurut Pendidikan dalam Program
Pembangunan Inrastruktur Jalan Pertanian
Pada Tahap Pelaksanaan

Dari Tabel 10 menunjukkan bahwa tingkat pedidikan SD yang aktif 5 orang kurang aktif 1 orang tidak aktif 1 orang dari 7 responden atau $35 \%$. Tingkat SMP yang aktif 5 orang tidak aktif 2 orang dari 7 responden atau $35 \%$. Tingkat SMA yang aktif 4 orang tidak aktif 1 orang dari 5 responden atau $25 \%$. Sedangkan PT hanya 1 orang kurang aktif dari 1 responden atau $5 \%$.

Tabel 11. Kategori Tingkat Partisipasi Masyarakat Dalam Pembangunan Infrastruktur Jalan Pertanian di Desa Buhias

\begin{tabular}{ccl}
\hline Tahapan & Skor & Kategori \\
\hline Perencanaan & 45 & Sedang \\
Pelaksanaan & 60 & Tinggi \\
\hline Total & 105 & \\
\hline Sumber Data: Diolah &
\end{tabular}

Sumber Data: Diolah dari Data Primer, 2018.

Dari hasil penelitian ini digunakan dua kategori untuk mengukur tingkat partisipasi yaitu partisipasi sedang, dan tinggi. Maka pengukuran jumlah skor tinggi partisipasi masyarakat dapat dilihat pada lampiran 3, yaitu dimana skor tiggi partisipasi masyarakat adalah 105 maka tingkat partisipasi masyarakat di Desa Buhias, berada di kategori tinggi.

\section{KESIMPULAN DAN SARAN}

\section{Kesimpulan}

Kesimpulan dari hasil penelitian ini bahwa tingkat partisipasi masyarakat dalam pembangunan infrastruktur jalan pertanian di Desa Buhias Kecamatan Wori Kabupaten Minahasa Utara, dilakukan dengan 2, (dua ) tahapan yaitu :

\section{Tahap Perencanaan}

Tahap perencanaan partisipasi masyarakat pada kategori yang sedang.

\section{Tahap pelaksanaan}

Tahap pelaksanaan partisipasi masyarakat pada kategori yang tinggi, dalam tahap ini semua masyarakat melibatkan diri untuk berpartisipasi dalam pembangunan infrastruktur jalan pertanian di Desa Buhias Kecamatan Wori Kabupatem Minahasa Utara. 


\section{Saran}

Perlunya pemerintah Desa harus awasi masyarakat selama kegiatan yang berlangsung, agar semua masyarakat terlipat dalam kegiatan yaitu tahap perencanaan, hingga tahap pelaksanaan agar pembangunan infrastruktur jalan pertanian yang ada di Desa Buhias Kecamatan Wori Kabupaten Minahasa Utara terlaksa dengan baik.

\section{DAFTAR PUSTAKA}

Adisasmita, Rahardjo. 2006. Pembangunan Pedesaan dan Perkotaan. Yogyakarta Graha Ilmu.

Isbandi, Rukminto Adi. 2007. Perencanaan Partisipatoris Berbasis Aset Komunitas: Dari Pemikiran Menuju Penerapan. Depok: Fisip UI Press.

Kodoatie, Robert J. 2005. Pengantar Manajemen Infrastruktur. Penerbit Pustaka Pelajar. Yogyakarta. 